International Journal of Life Sciences
Available online at http://sciencescholar.us/journal/index.php/ijls
Vol. 1 No. 2, August 2017, pages: $18 \sim 27$
e-ISSN: 2550-6986, p-ISSN: 2550-6994
http://dx.doi.org/10.21744/ijls.vi2.30

\title{
Environmental Impact On Electrical Networks Near The Manabita Litoral
}

\author{
Washington Colón Castillo Jurado a; Antonio Vázquez Pérez b; \\ Alcira Magdalena Vélez Quiroz ${ }^{\text {c; }}$ María Rodríguez Gámez ${ }^{\mathrm{d}}$
}

Article history: Received 3 February 2017; Accepted in revised form 10 July 2017; Approved 3 August 2017; Available online 10 August 2017

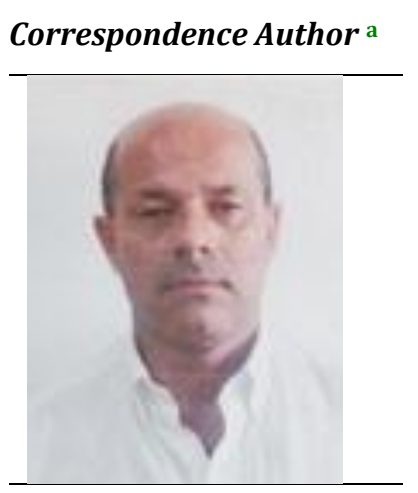

Keywords

Distribution;

Electricity Networks; Environmental Impact;

Maintenance;

Transmission;
Abstract

The coastal area of Manabita and its surroundings is one of the most beautiful regions of the province, with an extraordinary tourist attraction that has not yet been exploited in its entire dimension. In it are located beaches like the Murciélago, Crucita, San Jacinto among others, that throughout the year are frequented by national and international tourists, who come looking for tranquility and recreation. This paper analyzes the influence of the industrial process of coffee, fish and oil production, which are important in the generation of large amounts of air pollutants, combined with the effects of the marine aerosol, Clay dust produced by the quarries located in the area, which under wind effects deposition of polluting layers on the elements that make up the electrical infrastructure, causing a high contamination of nets and insulation, causing that during the rainy season, The dielectrics behave like conductors, causing as a consequence that affects the service in the territory, mainly during the winter. A brief evaluation is made of the consequences of environmental pollution on the system of electric lines, networks and insulators and what it may represent for the project proposed by the state to introduce the efficient cooking program (PEC).

a Doctorate program Universidad Técnica de Manabí, Faculty of Mathematical, Physical and Chemical Sciences, Portoviejo, Manabí, Ecuador.

b Doctorate Program, Local development, Universidad Técnica de Manabí, FCMFQ, Portoviejo, Ecuador.

c Doctorate program Universidad Técnica de Manabí, Faculty of Mathematical, Physical and Chemical Sciences, Portoviejo, Manabí, Ecuador.

d Ph.D. Universidad Técnica de Manabí, FCMFQ, Portoviejo, Manabí 
e-ISSN : 2550-6986, p-ISSN : 2550-6994@ Copyright 2017. The Author. SS Journals Published by Universidad Técnica de Manabí. This is an open-access article under the CC BY-SA 4.0 license (https://creativecommons.org/licenses/by-sa/4.0/) All rights reserved.

\section{Contents}

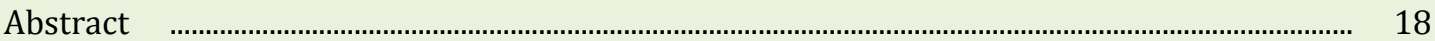

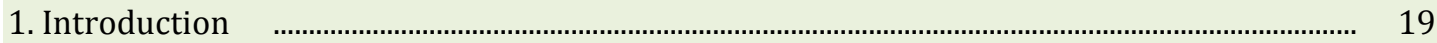

2. Research Method ～(.............................................................................................................. 20

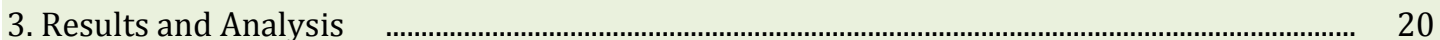

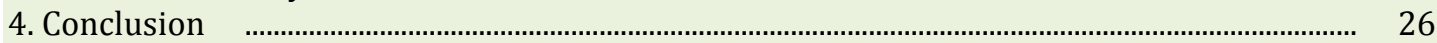

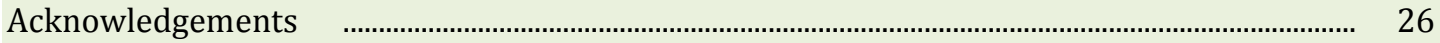

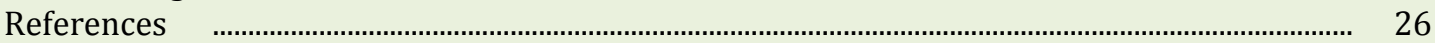

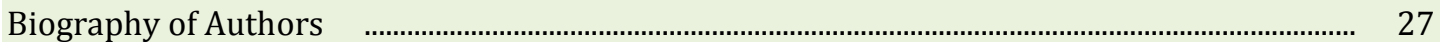

\section{Introduction}

Since the beginning of the discovery of electricity and its implementation, power lines have been subjected to different pollutant effects, being as varied forms of pollution, as broad can be the field of environmental impacts derived from activities linked to development.

The history of planet earth is the history of environmental pollution. There have always been impacts that are linked to the contamination of environmental conditions. Volcanic eruptions, dust storms, large wildfires and grasslands caused by natural phenomena are among the main causes that have a significant influence on the generation of atmospheric pollutants.

Ecosystems arise in nature with a certain energy balance. If this equilibrium is broken or altered, the ecosystem maintenance conditions change. When it exceeds the upper or lower limit of energy balance that allows resilience, it degenerates and runs the risk of disappearing if the system homeostasis does not allow it to restore equilibrium conditions. But air pollution began to rise above natural parameters, starting with the industrial revolution and especially after the second energy transition, when oil became the primary source of energy [1].

The largest source of aerosols due to human activity is the burning of fuels in thermal engines for transport and in thermoelectric plants for the generation of electric energy, in addition to dust generated in construction sites and other land areas where water or The vegetation has been removed. Pollution caused by emissions of polluting gases, heavy metals in suspension resulting from the combustion of hydrocarbons, both from power generation plants and from industries, from automobiles and homes, has been shown to be a major cause Respiratory diseases, skin and various types of cancer.

The other effect of emissions of pollutants into the atmosphere from combustion is that of acidic precipitation in the form of rain or mist. More than $80 \%$ of the sulfur dioxide, $50 \%$ of the nitrogen oxides, and 30 to $40 \%$ of the suspended particles emitted into the atmosphere come from fossil fuel power plants, industrial boilers, and heating systems. These pollutants are carried by wind and clouds, and produce adverse effects in areas very distant from the emission site in the form of a reservoir or acid rainfall [1].

The negative effects of acid rain have been seen on building materials, buildings, industrial equipment, monuments and architectural gems of antiquity. Electrical networks and insulators installed in the air mode are technical elements that have a high exposure to the effects of environmental pollution, which can increase as they are closer to the sources of pollution.

Environmental pollution is something that has no borders, capable of affecting not only those who emit it but can affect large areas away from the source of pollution. It is an effect that can be transported by the wind in the form of fog or aerosols, to any place by very closed, hidden and

Jurado, W. C. C., Pérez, A. V., Quiroz, A. M. V., \& Gámez, M. R. (2017). Environmental impact on electrical networks near the Manabita Litoral. International Journal of Life Sciences, 1(2), 18-27. https://doi.org/10.21744/ijls.v1i2.30 
far away that is, potentially spreads contaminating and affecting to as many elements of the means finds ahead.

Most citizens perceive the global nature of the pollution problem; That is why it is one of the main problems of the planet [2].

At present groups of countries are united to carry out programs of mitigation of environmental impacts, because the residues that are produced are dispersed from one place to another, either by the air or the waters, water table, etc. [3].

Some industries do not purify their waste, thus causing different conditions in their environment, not complying with international standards.

The extraction of building materials in the quarries between the Canton Portoviejo and Manta is associated with emissions, especially of particulate matter [4].

The CNEL electricity company in the province of Manabí has declared its environmental management system [5] for electricity networks, with a diagnosis of the effects they can generate in their environment, and the magnitude and importance of the impacts generated, as well As the proposal for the environmental management plan that allows to prevent and solve the problems encountered.

The problem that is addressed in the work is mainly related to the pollution caused by the industries located in the surroundings of the cantons Manta and Montecristi, as well as the economic consequences that derive from these affectations.

\section{Research Method}

The research work was carried out in the areas where the sub stations Montecristi I and Montecristí II are located.

The residual deposition was sampled in the infrastructure elements of the substations and isolators located in that territory.

It was possible to verify the polluting effect of the air, caused by the dust emissions derived from the operation of the quarries for the construction, as well as the gaseous emissions of the coffee roasting plant and despite the fact that the emissions of The other industries, in the infrastructure of the lines can be observed the traces of pollution linked to the rest of the industrial activity of the area.

The procedures have been the collection of samples at different distances from the main sources of pollution, as well as from the coast, which allowed the evaluation of the influence of the marine aerosol combined with the emissions of the industries, for which the geographic information system (GIS), which allowed the dispersion studies and the distance of the network.

\section{Results and Analysis}

CNEL Manabí is a company that is part of the Ecuadorian electricity sector, which, under the express mandate of the Constitutional President of the Republic, economist Rafael Correa Delgado, has taken on the challenge of having one hundred percent of the population of Manabí, And excellence [6].

CNEL is an institution that takes responsibility for the social and economic growth of Ecuador and especially of the province of Manabí, taking with high responsibility the tasks that make possible the permanent planning of the sector, in order to guarantee the electric service in The short, medium and long term, focused on meeting the demand of present and future generations.

Among the main goals of the Ecuadorian electricity sector are [6], to double generation capacity based on the use of renewable energy sources; Impulse of efficient thermal generation; To open a dynamic and efficient use of energy, in all segments of consumption, without affecting the comfort and quality of life of users; Large-scale introduction and generalization of induction cookers; Large-scale introduction of electric cars; Assume socio-environmental responsibility; Ensure the reduction of costs and security of electricity supply to users.

The Manabite power system is characterized by a strong generation deficit, with a thermal power plant with a nominal power of $40.40 \mathrm{MW}$ and an effective power of $32 \mathrm{MW}$, representing $15 \%$ of the province's demand, which is approximately of $206 \mathrm{MW}$, the rest of the demand 
comes from a base generation of hydroelectric plants that are between 120 and 400 kilometers away from the main cargo centers of the province, involving large losses and a high cost to maintain the technical quality of service.

The conditions under which a good part of the electricity service is served in the province of Manabí implies that for each $\mathrm{kWh}$ of electricity consumed, there must be generated between 2, 3 and more $\mathrm{kWh}$ in hydroelectric plants that are distant from the center of consumption.

In the network structure, there are 40 sub transmission lines with $721.91 \mathrm{~km}, 76$ medium voltage networks with 7,949.81 km and 215,300 low voltage lines with 13,729.59 km, 24 distribution substations with a power of 257 MVA and 17,576 Distribution transformers with a power of 468.98 MVA.

There is a total of 91,242 luminaires that accumulate a power of $21,372.47 \mathrm{~kW}$, for an average of 234 watts per luminaire, 212,546 meters and a total of 212,532 users controlled.

The province of Manabí is located in a portion of development zone No 4, which comprises the territory of the Coast or Coast, which covers $25 \%$ of the national territory. It has a population of $1,395,249$ inhabitants, with an annual growth rate of $1.65 \%$. The average age of the population is 28.2 years.

The territory of Manabi has a territorial area of $18400 \mathrm{~km}^{2}$, being the province more extensive of the coast. It limits the west with the Pacific Ocean, the north with the province of Esmeraldas, the east with the province of Santo Domingo de los Tsáchilas and Los Ríos, the south with the province of Santa Elena and the south and the east with the province of Guayas. It has a population of 1,395,249 inhabitants, is the third most populated province of Ecuador with 75.8 inhabitants per square kilometer.

In the relief of the province the extensive plains of the coastline that extend for 350 kilometers of coast bathed by the Pacific Ocean predominate, with some elevations inland that do not surpass the 800 meters on the level of the sea. In the Montecristi canton, there are isolated cords of the hills of this name and the hills of Leaves. To the north the Balzar Range, which includes the hills of Los Liberales and Canoa, is directed; From there follows a branch that joins with the hills of Jama and is continued towards the north with the hills of Coaque.

The climate oscillates between tropical dry and tropical humid and is determined by the marine currents; During the winter that begins in early December and concludes in May, the climate is hot and is influenced by the warm El Niño current. On the contrary, the summer from June to December is less hot, thanks to the cold Humboldt current, although the temperature is not uniform throughout the province, the average in Portoviejo the capital, is $25^{\circ} \mathrm{C}$ and in the city Of Manta, $23.8^{\circ} \mathrm{C}$.

The province has the third most populous metropolitan area in the country. The Conurbation Manabí Center, which is the most populous metropolitan region of the province and the 3rd in national ranking with 686,140 inhabitants. Portoviejo is considered the head of this conurbation and Manta the main port of the urban network. The 4 cantons that are within this conurbation, are considered suburban of Portoviejo and Manta. It is said that with more than 685,000 inhabitants, almost half of the population Manabita resides within this conurbation.

On the road from Portoviejo to Manta, there are several food processing industries, especially related to products such as the industrialization of coffee, fish, and oils. These industries are constantly emitting pollutants.

Among the industries with the highest incidence of pollutant emissions is the Molinera Manta, which has adopted an associative model with companies similar to its traditional activity, constituting a new business name called Moderna Alimentos S.A. In order to expand its field of action and consequently increase its wheat flour production capacity, which is why it has included in its plan the development of its manufacturing facilities [6] and therefore is expected to increase the level of emissions Atmospheric contaminants that affect the elements of the electrical infrastructure of the area.

In the city of Manta, Moderna Alimentos has the need to increase its production, which has led to the installation of new machinery, which is why CNEL established the need to improve the

Jurado, W. C. C., Pérez, A. V., Quiroz, A. M. V., \& Gámez, M. R. (2017). Environmental impact on electrical networks near the Manabita Litoral. International Journal of Life Sciences, 1(2), 18-27. https://doi.org/10.21744/ijls.v1i2.30 
quality of electricity supply, which is why it has decided to change Its current feeding station to another one of greater capacity, having decided to change its feeding voltage.

Among the main air pollutants emanating from the socioeconomic activities are [1].

- Monoxide and carbon (CO), derived from engine exhaust.

- Sulfur dioxide (SO2), originated in plants generating heat and electricity using oil or coal, with sulfur content, sulfuric acid plants.

- Particles in suspension, derived from the escape of motor vehicles, industrial processes, incineration of waste, generation of heat and electricity, and the reaction of polluting gases in the atmosphere.

- Lead $(\mathrm{Pb})$, from exhaust gases from motor vehicles, lead smelters, battery factories.

- Nitrogen oxides (NO, NO2) from exhaust fumes from motor vehicles, heat and power generation, nitric acid, explosives and fertilizer factories.

- Non-methane hydrocarbons (including ethane, ethylene, propane, butanes, pentanes, acetylene) from exhaust fumes from motor vehicles, solvent evaporation, industrial processes, solid waste disposal and fuel combustion.

- Carbon dioxide (CO2) from all sources of combustion.

- In certain areas where there are quarries and dusty areas, the air is usually impregnated with a very fine almost imperceptible dust, which permanently weakens the atmosphere, with the potential to combine with the rest of the gases and complicate the level of pollution environmental.

- Spraying of seawater is considered the second most important source of aerosols globally. In the coastal zones, the sea water is usually sprayed, which combined with the action of the wind, becomes a colloid of mainly liquid microparticles suspended in the air with a size that can be from $0.002 \mu \mathrm{m}$ to more than $100 \mu \mathrm{m}$, Which are charged with a strong sodium chloride component, magnesium, calcium, potassium and sulphate salts, which are very harmful to metal structures due to their high corrosion level. In addition, marinebased aerosols may contain organic compounds

\subsection{Influence of marine aerosol and other agents on the reliability of the electrical network}

The marine aerosol is an agent caused by the breaking of the waves on the coasts of the coasts, this is dispersed in the form of haze at different distances, depositing in the different elements that make up the environment, among which are the conductors and insulators of the transmission and distribution system of electricity and becomes small drops of water with a high level of salinity. At daylight hours the water evaporates as a result of solar heating and salt is embedded in the elements of the electrical infrastructure, with the possibility of affecting the dielectric property of the insulators, which in combination with the rains can cause technical conditions in the Network and with it interruptions and the decrease of the quality and effectiveness of the service to the users.

\subsection{Emissions of polluting gases from coffee roasting}

The coffee roasting industry is located on the road to Manta, in the vicinity of the canton Montecristi. In this factory, the coffee roasting is carried out, with a working regime 24 hours a day and constitutes one of the main sources of gaseous contamination of the area.

Figure 1 shows images of the gaseous emissions that can be observed daily in the coffee industry located in the vicinity of Montecristi, on the road to Manta. 


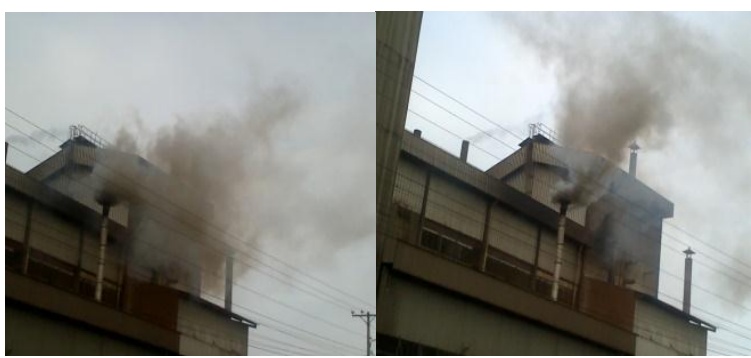

Figure 1. Emissions from the coffee industry

The smoke is dispersed by the wind, occurring that the release of contaminating oily substances are impregnated in the electrical infrastructure, especially in the insulators, that combined with the marine aerosol and the dust coming from the quarries of the construction and of the own conditions of the Create a crust on the elements of the networks

\subsection{Pollutant emissions from other industries}

Among the other industries are the Manta mill, the tuna conservation factories, the Bilbosa that industrializes the oil of Palma Africana, and all of them polluting the air at the same time, increase emissions levels, but with components Different chemicals, creating greater pollution problems in the electrical infrastructure.

During the construction and assembly period of the substation Montecristi II, some samples were taken from the depositions of the already mentioned pollutant emissions. Figure 2 shows an image of the fans of the transformers, where the pollution levels are observed. In this case the majority of the contaminant depositions come from the quarries that are close to the substations under study, that is to say, that preventive maintenance must be done before starting the substation because it is not only the isolators that can be affected because the contamination

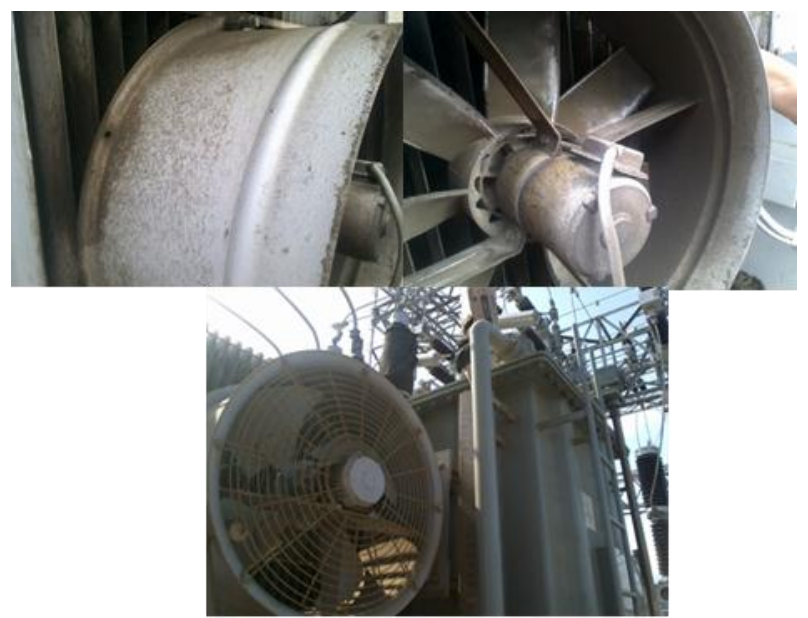

Figure 2. Deposition of the quarry dust in the fans of the substation

As you can see even before the substation goes into operation, it already needs maintenance cleaning, because there are layers of pollutants that have been deposited in the equipment and that need to be removed by the operators to put them into operation.

In winter, after the summer months where there is almost no rain, the insulators and other components of the transmission and distribution network infrastructure have accumulated sufficient pollution and the situation can be aggravated by the first rains and when the Deposition of different components has already become a very robust layer, which in the winter period causes the water particles in the insulator to roll over that layer, disrupting the dielectric

Jurado, W. C. C., Pérez, A. V., Quiroz, A. M. V., \& Gámez, M. R. (2017). Environmental impact on electrical networks near the Manabita Litoral. International Journal of Life Sciences, 1(2), 18-27. https://doi.org/10.21744/ijls.v1i2.30 
property of the insulators becoming conductors, involving technical faults With potential to cause interruptions in the electric service, with its consequent economic losses, not only for the electric company, but also for the users. In the image of Figure 3, insulators deteriorated due to contamination.

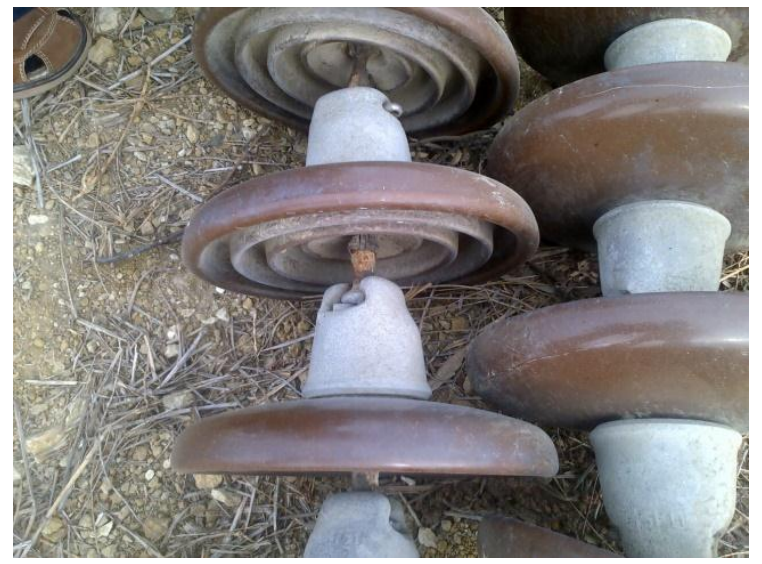

Figure 3.Sample of insulators deteriorated due to contamination

The consequences of the contamination are that the actions of maintenance of the electrical infrastructure are of greater periodicity, implying an excess of expenses of resources by the local electric company of the province of Manabí. In the Figure 4 different images of the maintainers of the electric lines are observed in full task, being able to appreciate the complexity of the task, which involves high risks for the workers who carry out the cleaning and maintenance work.

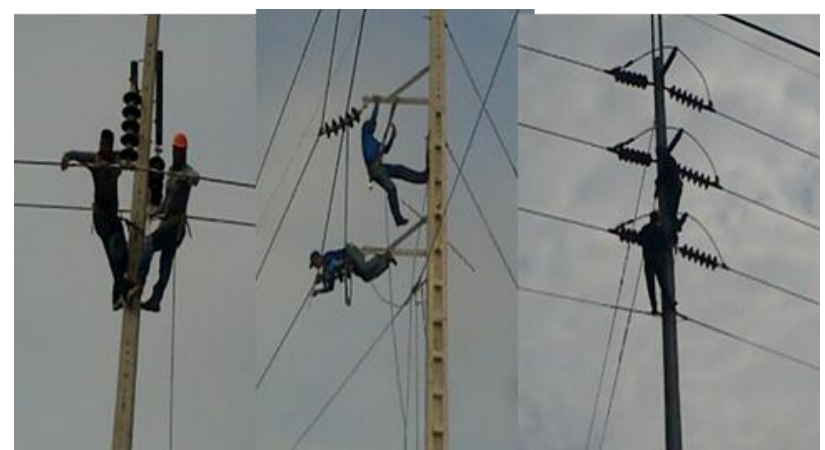

Figure 4. Electrical workers cleaning and maintaining networks

These images are frequent to observe the weekends (Saturdays and Sundays) of 6 to 9 of the morning, in any zone of the territory manabita, fundamentally in the section of the highway Montecristi via Manta that is one of the sites more affected.

So far, a group of substations has been identified, which show the greatest effects derived from emanations from polluting sources. Table 1 shows the substations with the highest impacts in terms of environmental pollution. 


\begin{tabular}{cll} 
Tabla 1. Sub-estaciones afectadas por emisiones contaminantes \\
\cline { 2 - 3 } No. & \multicolumn{1}{c}{ Address } & \multicolumn{1}{c}{ Substation } \\
\hline 1 & Via Rocafuerte & Manta 2 \\
2 & Neighborhood San Pedro / Manta & Manta 3 \\
3 & Neighborhood Miraflores / Manta & Manta 1 \\
4 & From to El Café & Montecristi \\
5 & Via San Juan de Manta & Manta 4 \\
6 & Redondel the Colorado & Montecristi 2 \\
\hline
\end{tabular}

When analyzing the contents of Table 1, it can be verified that the substations registered as the most affected, coincides with areas of high industrialization, so it can be assumed that the interruptions of the service to carry out the maintenance, can affect the compliance of The production plans of these industries, with a specific economic result, to which must be added the cost of maintenance proper to the system of the electricity networks by the electricity company. Figure 5 shows the relief map of the province of Manabí and the most important elements of the affected electrical infrastructure in a perimeter of $15 \mathrm{~km}$.

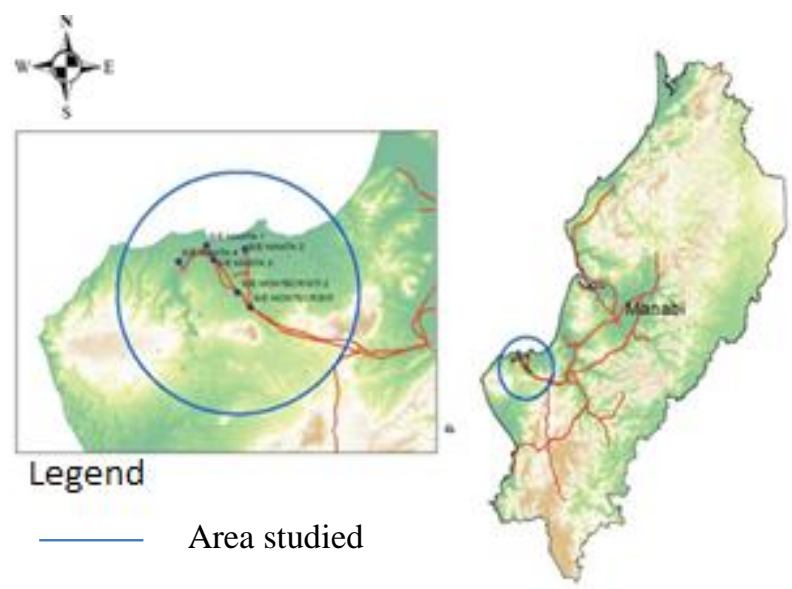

Figure 5. Affected elements in a perimeter of $15 \mathrm{~km}$

Previously we have already discussed the incidence of environmental pollution on insulators, which implies that in the areas most affected, it is necessary to carry out well-detailed analyses on the type of contamination and the types of insulators to be used in each case.

Mainly new investments should require a specific environmental assessment of sites that will be intervened with the technology and as a consequence to anticipate corrective actions or mitigation of impacts that are required, which will allow a lower level of affectations derived from environmental influence, Assuming the reduction of economic losses by that concept.

In previous research on the subject, it has been possible to verify that there are three fundamental types of pollution that affect the elements of the technical infrastructure of the electricity grid system; The navy, the industrial and the desert [7].

The investigations and evaluations made it possible to verify that the three types of pollution mentioned above are present in the study area, demonstrating the high level of complexity involved in the search for a possible solution aimed at reducing the consequences associated with environmental effects that are presented.

The results obtained can tax the re-elaboration of a new system of environmental management specific to the study area, which under the current environmental legislation in Ecuador allows the design of measures tempered to the specific situation that occurs in the area

Jurado, W. C. C., Pérez, A. V., Quiroz, A. M. V., \& Gámez, M. R. (2017). Environmental impact on electrical networks near the Manabita Litoral. International Journal of Life Sciences, 1(2), 18-27. https://doi.org/10.21744/ijls.v1i2.30 
Affected, where in addition to the company CNEL, link the actions and resources of the industries committed to the polluting emissions

\section{Conclusion}

By conducting a preliminary research project, it was possible to define the initial situation presented by the elements of the technical infrastructure of the electricity grid system in the province of Manabí, in relation to the effects of environmental pollution derived from the activity Industrial and its combination with the climatic components and the marine aerosol, defining the areas most affected by this phenomenon.

\section{Acknowledgement}

The university administration is grateful for the development of this research work.

\section{References}

1. Altshuler, J. and y colectivo de autores, Tabloide de energía. suplemento especial. . Editorial Academia, Cuba, 2004.

2. Arcentales, G. A. T., Lucas, M. A. P., Guerrero, J. A. C., \& Gordín, R. G. (2017). Evaluation for the Reduction of NH3 Contamination Risks. International Journal of Life Sciences (IJLS), 1(2), 10 17.

3. Arnawa, I. K., Sukerta, I. M., Martiningsih, N. G. A. E., \& Astuti, P. S. (2017). Minapolitan Area Development Strategy: An Effort to Increase Fisherman Income, Gianyar Regency, Bali Indonesia. International Journal of Life Sciences (IJLS), 1(2), 39-47.

4. Castro, M., Mapas de niveles de contaminación del aislamiento de la República de Cuba. Informe de investigación del programa Energético (PR-585). CIPEL. Cujae. , 1989.

5. CONELEC, Atlas del sistema eléctrico del Ecuador. Publicación anual del MEER, CONELEC y TERRASOE, 2009.

6. Daniel Gil Pérez, A.V. and J.C.T.y.O. Macías., Década de la Educación para un futuro sostenible (2005-2014). Un punto de inflexión necesario en la atención a la situación del planeta . Revista Iberoamericana de Educación 40, pp.125-178 2006.

7. Enrique Lendo Fuentes, M.J.D., Programa Frontera 2012. Programa Ambiental MéxicoEstados Unidos. http://www2.epa.gov/ (Consultado enero 2015). 2012.

8. Jain, P., Jain, A., Singhai, R., \& Jain, S. (2017). Effect of Biodegradation and Non Degradable Substances in Environment. International Journal of Life Sciences (IJLS), 1(1), 58-64.

9. Jurado, W. C. C., Pérez, A. V. P., Quiroz, A. M. V., \& Gámez, M. R. (2017). Environmental Impact On Electrical Networks Near The Manabita Litoral. International Journal of Life Sciences (IJLS), 1(2), 18-27.

10. Medioambiente, M.d., Inventario Preliminar de las Emisiones de Contaminantes del Aire, de los cantones Ambato, Riobamba, Santo Domingo de los Colorados, Latacunga, Ibarra, Manta, Portoviejo, Esmeraldas y Milagro. Repositorio ddel Ministerio de Meido Ambiente Ecuador., 2014. http://www.ambiente.gob.ec/wp-content (Consultado enero 2015),.

11. Ogu, G. I., \& Orjiakor, P. I. (2017). Microbiological and Nutritional Qualities of Fermented Melon Seed Shells. International Journal of Life Sciences (IJLS), 1(2), 1-9.

12. Ogunsiji, A. S., \& Ladanu, W. K. (2017). A Theoretical Study of Performance Measures in the Strategic and Corporate Entrepreneurship of Firms. International Journal of Life Sciences (IJLS), 1(1), 49-57.

13. Omer, A. M. (2017). Identifying, Developing, and Moving Sustainable Communities through Application of Bioenergy for Energy or Materials: Future Perspective through Energy Efficiency. International Journal of Life Sciences (IJLS), 1(1), 9-39.

14. Saxena, A. (2017). The Impact of Nutrition on the Overall Quality of Life Adolescent Girls are Living Across the City of Kota. International Journal of Life Sciences (IJLS), 1(1), 40-48.

15. Singh, D. (2017). Leaf Phenology of Cassia Sieberiana L. in KSUSTA Campus of Kebbi State, Nigeria. International Journal of Life Sciences (IJLS), 1(1), 1-8. 
16. Sulistiawati, N. P. A., Kartini, L., \& Yuliartini, M. S. (2017). Identification of Development Phases and Changes Shoots Flowering Orange Siam Plants. International Journal of Life Sciences (IJLS), 1(2), 28-38.

17. Sutapa, I. K., Sutapa, I. N., \& Susila, I. N. D. (2017). Implementation of Active Rest in Participatory Ergonomics Decrease Workload and Women Musculoskeletal Complaints of Parking in Mall Ramayana Denpasar. International Journal of Life Sciences (IJLS), 1(2), 48-54.

18. V., P.R., Declaración de impacto ambiental de las líneas de subtransmisión Manta 2 - Jaramijó y subestación Jaramijó" provincia de Manabí. www.CNEL.gob.ec (Consultado nero 2015). 20114.

\section{Biography of Authors}

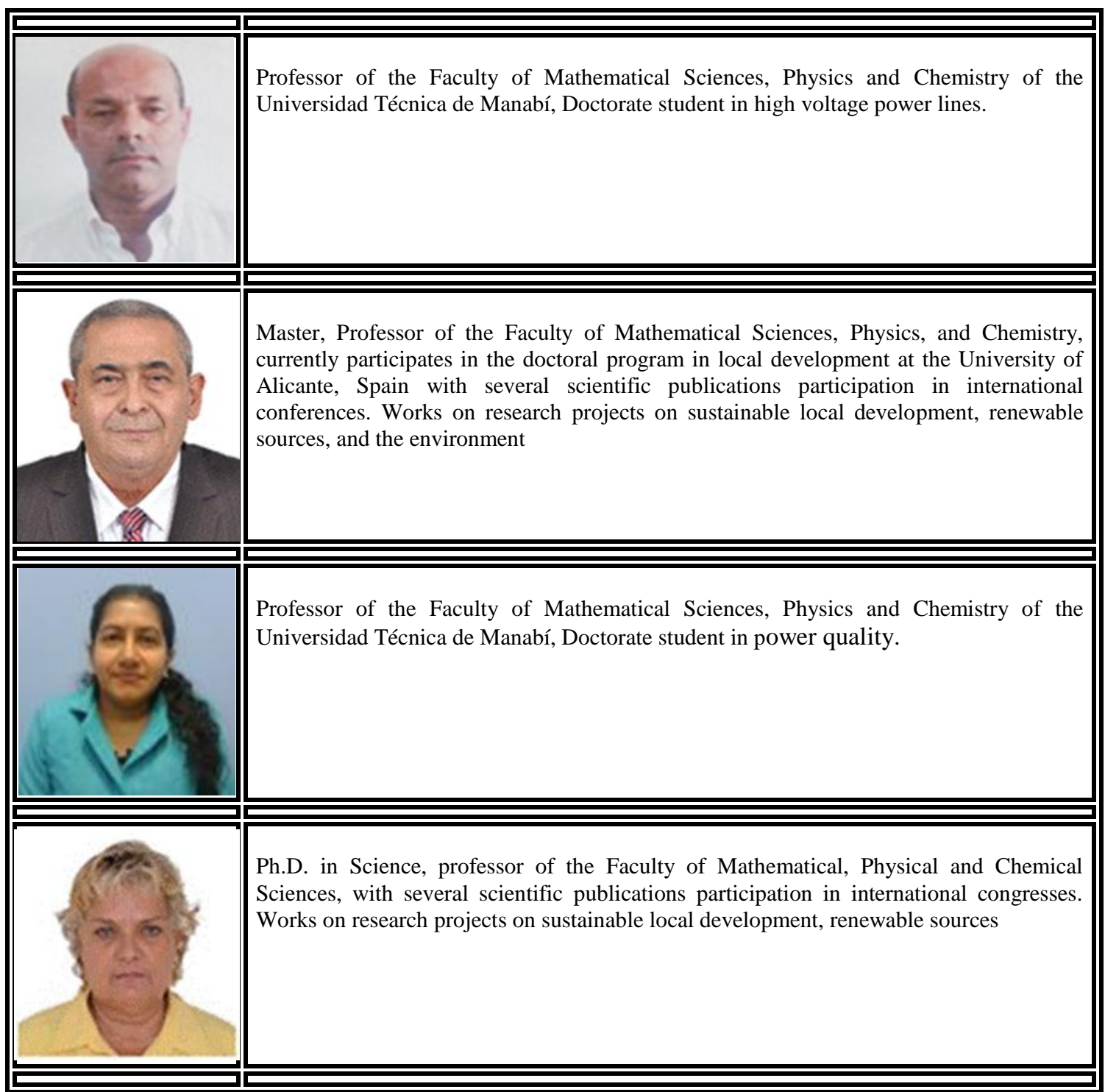

Jurado, W. C. C., Pérez, A. V., Quiroz, A. M. V., \& Gámez, M. R. (2017). Environmental impact on electrical networks near the Manabita Litoral. International Journal of Life Sciences, 1(2), 18-27. https://doi.org/10.21744/ijls.v1i2.30 